\title{
Cloning and Expression of Dynorphin-32 in E. coli and Analgesic Tests in Mice Models
}

\author{
Venkateshwara Rao Joginapally ${ }^{1}$ \\ ${ }^{1}$ Department of Zoology, University College of Science, Osmania University, Hyderabad, Telangana, India.
}

\section{ABSTRACT}

\section{BACKGROUND}

Chronic severe pain is most destructive to the human psyche. Presently available analgesics are effective in the treatment of acute pain, although even in this setting "analgesic gaps" remain. But for chronic pain, there is a need to develop better therapeutic strategies and analgesics than are currently available. Epidemiologic data indicates that even in prosperous, developed nations, $40 \%$ of patients with chronic pain are only partially satisfied and $15 \%$ are not satisfied at all with the treatments available to them. At the same time, proper treatment of pain is increasingly in demand as a human right by patients, their families, and governments. Therefore, modern medicine urgently needs more effective treatments for pain. Therefore, the challenge of this decade is to produce small molecules which mimic chemical drugs, in order to overcome the ineffectiveness of currently available analgesic drugs. This work includes identification of target receptors, selection of potent existent drugs, modelling, and selection of peptide based therapeutic drugs.

\section{METHODS}

The selected mutant sequences of analgesic peptides were codon optimized using DNA 2.0 software for maximum expression in Saccharomyces cerevisiae and E. coli. Codon optimization was carried out at above $15 \%$ threshold and as per the codon usage frequency of standard Saccharomyces and E. coli tables. For yeast Alpha F mating tag and for E. coli ompA tag was used for efficient extracellular recombinant expressions. The expression studies were carried out initially in E. coli with analgesic peptides. Lac promoters were used for induction of the genes of these analgesic peptides. These peptides were also precipitated using acetone and used for the analysis. Partially purified analgesic peptides by salt and acetone precipitation were used for bioassays by Tail immersion and hot plat assays.

\section{RESULTS}

Positive confirmed constructs were transformed in BL21 for expression. Dynorphin recombinants in BL21 were used for expression studies. The expression of recombinant protein was confirmed by $16 \%$ SDS PAGE. The over expressed peptide was first precipitated by ammonium sulphate and dialyzed. The dialyzed samples were used for bioassay studies. Fentanyl was used as positive control and uninduced culture broth as negative control. Among the three peptides studied JV5 (Peptide F) showed $62 \%$ central analgesic activity (observed by tail immersion assay) when compared to fentanyl by oral route of administration and fentanyl treatment (hot plate assay) indicating similar action suggesting usage of this peptide as strong analgesic molecule for future pain treatments.

\section{CONCLUSIONS}

Analgesic peptides are promising candidates to replace chemical based opioid drugbased treatments in patients to get relief from pain during medical treatments. In the current study, synthetic mutated peptide Dynorphin is showing amicable results comparable to that of $50-60 \%$ of standard analgesics i.e. fentanyl compounds present in the market.

\section{KEY WORDS}

Cloning, Dynorphin, Analgesic Peptide, Hot Plate Method, Tail Immersion Method.
Corresponding Author:

Dr. Venkateshwara Rao Joginapally,

Assistant Professor,

Department of Zoology,

University College of Science,

Osmania University,

Hyderabad-500007, Telangana, India.

E-mail:venbio@gmail.com

DOI: 10.14260/jemds/2020/350

Financial or Other Competing Interests: Dr. Joginapally reports grants from Department of Biotechnology (DBT), during the conduct of the study.

How to Cite This Article:

Joginapally VR. Cloning and expression of dynorphin-32 in E. coli and analgesic tests in mice models. J. Evolution Med. Dent. Sci. 2020;9(20):1604-1607, $10.14260 /$ jemds/2020/350 DOI:

Submission 18-03-2020,

Peer Review 02-05-2020,

Acceptance 09-05-2020,

Published 18-05-2020. 


\section{BACKGROUND}

Opiate alkaloid molecules are very rigid, whereas opioid peptides are very flexible. This fundamental distinction leads to differences in the mechanism of these molecules' interaction with opioid receptors. Rigid alkaloids probably interact by means of an "induced-fit" mechanism, in which the receptor adopts a local pocket structure to the alkaloid's conformation, whereas peptides interact via a "zipper" mechanism in which both the peptide molecule and the binding pocket change their structure to optimize their interaction. Because the final biological effect of interactions of both types of molecules is identical, one might speculate that the general structures of the final ligand-receptor complexes are identical or very similar. Therefore, identification of equivalent groups in series of nonpeptidic and peptidic opioid ligands is an important goal of structureactivity.

Peptide chemists identified several small peptides like Biphalin, Tachykinin, with potent analgesic activity whereas, due to high production cost and instability and impurity profile many of the peptides developed in this process have not successfully completed the clinical trials. Biotechnology by rDNA technology will provide an option for large scale production and uniform product obtaining of analgesic peptides. Hence in the present work reveals production of novel analgesic peptides and expressed in suitable host organisms and pain tolerance check on animal models.

Pain can be simply expressed as an undesirable trait of physical or emotional level of experiences by an individual. Pain is one of the most important reason for which individual need medical assistance. But treatments to chronic pain are always are a major problem because of the chemical drugs and their undesirable side effects to the patients. Opioids are from the beginning of times employed as most potent analgesic therapeutic molecules to control the pain modulations.(1,2) Their course of action involves in management of the pain signal transmission cascades to Central nervous system (CNS).

Because of their tremendous power in controlling pain relieving properties, they are more sorted of candidates to treat several pain related disorders, but systemic administration of these candidates can carry some un necessary complications and side effects which majorly contributed to their core of actions with opioid receptors that include depression, respiratory problems, tolerance and addiction. The accelerated research works in to peripheral nervous system which is outside from CNS, leads to novel discoveries of peripheral opioid receptors which are situated on the peripheral sensory neurons. . $^{3,4)}$ This was well accepted by scientific community and clinically proven analgesia was produced from peripheral opioid receptors activation. ${ }^{(5,6)}$ At the same time interestingly, the treatment through peripheral opioid receptor system is devoid of side effects with Central Nervous System (CNS) which is a hallmark in treatment of pain related disorders. (4) Most of the inflammatory pathways results in a condition known as hyperalgesia in which for example arachidonic acid cascades they result in an analgesia peripheral endogenous in nature, which shows enhancement of opioid receptors expression on the peripheral regions at the terminal portions of sensory neurons which results in increased the site specific manufacture of specific opioid peptides at the locality through the inflammations. $(5,6)$

Thus, it makes us clearly understand an idea about the functionality of immune system in improving analgesic responses in reply to harmful notorious stimulus. In inflammation effected tissues, peptides which belongs to opioid class such as dynorphin A (DYN A), beta-endorphin ( $\beta$-END) and methionine-enkephalin (met-ENK) produced specific analgesic through respective opioid receptor interactions which are released upon stimulation by corticotrophin- releasing factor (CRF), interleukin-1beta (IL-1 $\beta$ ), and noradrenaline.(7-9)

\section{METHODS}

A. Cloning of Wild and Mute in Sequences in Suitable Host Organisms for Maximum Expression and Activity

The selected mutant sequences of Dynorphin synthetic peptides (DN1-3) were codon optimized using DNA 2.0 software for maximum expression in E. coli. Codon optimization was carried out at above $15 \%$ threshold and as per the codon usage frequency of standard E. coli tables. For E. coli ompA tag was used for extracellular expression.

\section{B. Secretary Signals in E. coli}

ompA and amino acid sequences of MKKTAIAIAVALAGFATVAQA were used. As wild sequences showed very little activity and many points were identified for mutagenesis, instead of using conventional site directed mutagenesis methods engineered synthetic genes were designed and purchased from Gene Art, Germany. Strains and Vectors used in the study. A: Bacteria; Strain 1: DH5 alpha; Vector Used: pET22b; Strain 2: BL21 (DE3); Vector Used: pET22b

\section{Codon Optimization}

has been carried out for maximum expression in yeast and E. coli. The designed specific synthetic genes were synthesized at Gene Art, Germany. The analgesic peptides were named as: DN1-5.

\section{Dynorphin-32 \\ AA Sequence \\ GGWLRRIRPKLKWDNQKRYGGFLRRQFKVVT}

Codon optimization Seq

TATGGTGGTTGGCTGCGTCGTATTCGTCCAAAACTGAAATGGGA

TAATCAAA

AACGTTATGGTGGTTTTCTGCGTCGTCAATTTAAAGTTGTTACT

\author{
E. Finalized Sequence after Bioinformatics Analysis Using \\ DNAStar 2.0 Software \\ AAGCTTGAATTCATGAGATTTCCATCTATTTTTACTATAGTTTT \\ GTTTGCTGCA \\ TCTTCAGCTTTGGCAGCTAGCTATGGTGGTTTTATGAAAAAAAT \\ GGATGAACT
}


GAAACCACTGGAAGTTGAAGAAGAAGCTAATGGTGGTGAAGTT CTGGGTAA

ACGTTATGGTGGTTTTATGTAATAGGGTACCAGATCTGCGGCCG CGGATCC

Standard recombinant DNA techniques were performed as described by Sambrook et al., (2001). Isolations were carried out by using Qiagen kits as per the manufacturers' instructions.

\section{Transformation}

Synthetic genes were provided in plasmids. These plasmids were transformed in Top 10 cells by $\mathrm{CaCl}_{2}$ transformation.

\section{Plasmid Isolation}

Plasmid cultures were grown in sensitive antibiotic medium and plasmid was isolated by Qiagen Kit.

\section{Expression and Purification of Recombinant Analgesic Dynorphin Clone}

Expression and purification of recombinant AGAP was primarily performed according to the Novagen pET system manual. Escherichia coli BL21 (DE3) cells harbouring pET28 expression vector were grown at $37 \mathrm{C}$ in LB medium in the presence of kanamycin. Recombinant protein synthesis was induced at late logarithmic phase (OD600 1/4 0:8-1.0) by addition of $0.1 \mathrm{mM}$ IPTG. Cells were harvested $3 \mathrm{~h}$ later, washed and resuspended in $5 \mathrm{mM}$ imidazole, $0.5 \mathrm{mM} \mathrm{NaCl}, 20$ $\mathrm{mM}$ Tris, $\mathrm{pH}$ 7.9. The supernatant of expressing cells after lyses by sonication was collected from culture liquid medium and applied on the His bind column. The column was washed with binding buffer ( $5 \mathrm{mM}$ imidazole, $0.5 \mathrm{mM} \mathrm{NaCl}, 20 \mathrm{mM}$ Tris, pH 7.9), wash buffer ( $60 \mathrm{mM}$ imidazole, $0.5 \mathrm{mM}$ sodium chloride, $20 \mathrm{mM}$ Tris, pH 7.9) and elute buffer (1 M imidazole, $0.5 \mathrm{mM} \mathrm{NaCl}, 20 \mathrm{mM}$ Tris, $\mathrm{pH} 7.9$ ) subsequently at a flow rate of $1 \mathrm{ml} / \mathrm{min}$. The eluent was desalted and concentrated with Pall stirred ultra-filtration cells (3 kDa membrane), and analyzed by SDS-PAGE.

\section{Animals}

Pharmacological experiments were carried out using Swiss male albino mice weighing 20-25g. The animals were randomly grouped in polyacrylic cages and maintained under standard animal housing conditions (temperature $25^{\circ} \pm 2^{\circ} \mathrm{C}$ ) and relative humidity $(40-70 \%)$ with dark-light cycles $(12 / 12 \mathrm{~h})$. The mice had free access to water. The mice were acclimatized to laboratory condition for 1 day before experimentation. Animals had no access to food during the whole day of experiment. Animal care and handling for the research were performed in accordance with the regulations and guidelines stipulated by the Institutional Animal Care and Use Guidelines.

\section{Assay of Analgesic Activity in Hot-Plate Procedure}

The hot-plate assay was done as described by Callaghan and Holtzman. Female mice of 18-22 g were put on the hot plate, whose temperature is $5505 \mathrm{C}$ to induce pain of their body. In response the mouse would lick or kick its feet, so that the time from putting the mice onto the hot plate to its licking or kicking action could be counted to reflect the intensity of pain. To perform bioassay, samples were injected intravenously in advance. Then measure the time from putting it on the hot plate to its licking or kicking action at the 25 th minute. If this time is more than $60 \mathrm{~s}$, take the mice away the hot plate at once to prevent from the damage and count the time as $60 \mathrm{~s}$. Pain killer was used as controls.

\section{Tail Flick Test}

Mice were divided into nine groups of 6 mice each. Group I served as negative control and received the vehicle (DMSO + water, 1:1), where groups II, III, IV, V, VI, VII, and VIII received PLE at doses 12.5, 25, 50, 75, 100, 150, and $200 \mathrm{mg} / \mathrm{kg}$, respectively. Group IX was injected by morphine sulphate $5 \mathrm{mg} / \mathrm{kg}$ to act as positive control. All drugs were injected intraperitoneally $(50 \mu \mathrm{l}), 30 \mathrm{~min}$ prior to the experiment. Pain was induced by placing on the tail flick instrument.

\section{RESULTS}

\section{Animal Observation}

\begin{tabular}{|c|c|c|c|c|c|}
\hline \multicolumn{6}{|c|}{ Analgesic Studies with Acetone Precipitated Analgesic Peptides } \\
\hline $\begin{array}{l}\text { Mice } \\
\text { No. }\end{array}$ & $\begin{array}{c}\text { +ve Control }^{\text {ve }} \\
\text { Fentanyl Group }\end{array}$ & $\begin{array}{c}\text { Group } 1 \\
\text { (DN-1) }\end{array}$ & $\begin{array}{c}\text { Group } 2 \\
\text { (DN-2) }\end{array}$ & $\begin{array}{c}\text { Group } 3 \\
\text { (DN-3) }\end{array}$ & $\begin{array}{c}\text { Group } \\
4\end{array}$ \\
\hline \multicolumn{6}{|c|}{ Tail Immersion Test response of Mice Time in Seconds } \\
\hline M1 & 62 & 18 & 15 & 29 & 9 \\
\hline M2 & 66 & 17 & 15 & 28 & 7 \\
\hline M3 & 65 & 15 & 13 & 26 & 6 \\
\hline M4 & 66 & 18 & 21 & 26 & 6 \\
\hline M5 & 57 & 17 & 20 & 24 & 5 \\
\hline M6 & 64 & 19 & 23 & 23 & 7 \\
\hline M7 & 69 & 18 & 19 & 22 & 5 \\
\hline M8 & 64 & 16 & 18 & 21 & 8 \\
\hline \multicolumn{6}{|c|}{$\begin{array}{c}\text { Table 1. Bioactivity of Recombinant Analgesic Peptides } \\
\text { Tail Immersion Method }\end{array}$} \\
\hline
\end{tabular}

\begin{tabular}{|c|c|c|c|c|c|}
\hline \multicolumn{6}{|c|}{ Analgesic Studies with Acetone Precipitated Analgesic Peptides } \\
\hline $\begin{array}{c}\text { Mice } \\
\text { No. }\end{array}$ & $\begin{array}{l}+{ }^{\text {ve }} \text { Control } \\
\text { Fentanyl Group }\end{array}$ & $\begin{array}{c}\text { Group } 1 \\
\text { (DN-1) }\end{array}$ & $\begin{array}{c}\text { Group } 2 \\
\text { (DN-2) }\end{array}$ & $\begin{array}{c}\text { Group } 3 \\
\text { (DN-3) }\end{array}$ & $\begin{array}{c}\text { Group } \\
4\end{array}$ \\
\hline \multicolumn{6}{|c|}{ Tail Immersion Test response of Mice Time in Seconds } \\
\hline M1 & 6 & 4 & 4 & 4 & 5 \\
\hline M2 & 5 & 4 & 3 & 4 & 2 \\
\hline M3 & 8 & 6 & 5 & 6 & 2 \\
\hline M4 & 6 & 5 & 5 & 4 & 3 \\
\hline M5 & 7 & 6 & 5 & 6 & 3 \\
\hline M6 & 4 & 5 & 4 & 5 & 4 \\
\hline M7 & 7 & 5 & 6 & 5 & 4 \\
\hline M8 & 8 & 6 & 5 & 6 & 5 \\
\hline \multicolumn{6}{|c|}{$\begin{array}{l}\text { Table 2. Bioactivity of Recombinant Analgesic Peptides: } \\
\text { Hot Plate Method }\end{array}$} \\
\hline
\end{tabular}

\section{DISCUSSION}

Three mutated clones of Dynorphin were prepared by using DNA Star 2.0 Software by codon optimization methods of $E$. coli codon tables. The clones were fused with OmpA secretory tags for extracellular secretion in E. coli Cells. Clones were checked on Agarose gels for proper gene of Insertion and 
found the plasmids are expressed. The clones were cultured in shake flask cultures. The induced proteins were extracted using Sodium bisulphate and Gel Filtration methods. The partially purified proteins were checked for peptide presence on $12 \%$ SDS PAGE gels. The bands have clearly showed expression of peptides of approximately 7-8 K. Da size. The partially purified proteins were used to test analgesic activity in animal models using Hot plate method and Tail Immersion Methods (Table 1 and 2). Among DN1 and DN2 and DN3 mutant peptides DN3 has showed maximum analgesic effect on mouse models but comparatively $50-60 \%$ of standard Fentanyl compounds.

Three mutated clones of Dynorphin were prepared by using DNA Star 2.0 Software by codon optimization methods of $E$. coli codon tables. The clones were fused with OmpA secretory tags for extracellular secretion in E. coli Cells. Clones were checked on Agarose gels for proper gene of Insertion and found the plasmids are expressed. The clones were cultured in shake flask cultures. We obtained yields of $2.5 \mathrm{mg} / \mathrm{L}$. It is found highest expression of recombinant studies of other proteins like Human interferon gamma, alpha and Glutathione are $42.5 \mathrm{~g} / \mathrm{L}, 4.4 \mathrm{~g} / \mathrm{L}$ and $880 \mathrm{mg} / \mathrm{L}$ respectively. (7-12) The induced proteins were extracted using Sodium bisulphate and Gel Filtration methods. The partially purified proteins were checked for peptide presence on $12 \%$ SDS PAGE gels. The bands have clearly showed expression of peptides of approximately 7-8 K. Da size.

The partially purified proteins were used to test analgesic activity in animal models using Hot plate method and Tail Immersion Methods (Table 1 and 2). According Table 1, results show that Fentnyl drug which is commercially wellknown available drugs showing high analgesic activity in all the groups of mice models in which experiments were carried out showing maximum activity in the group M7 with a value of 69 Seconds. The Confidential Values are 90-99.9\% respectively and Margin of Errors 64.125 \pm 2.049 ranging from $3.20 \%$ to $8.58 \%$. Statistically showing significance levels of DN3 are $\mathrm{p}<0.001$ when compared with Positive control.

According Table 2, results show that Fentanyl drug which is commercially well-known available drugs showing high analgesic activity in all the groups of mice models in which experiments were carried out showing maximum activity in the group M3 and M8 with a value of 8 Seconds. The Confidential Values are 68.3 to $99.9 \%$ respectively. Standard Mean Margin of Errors are $6.375 \pm 0.498$ ranging from $7.81 \%$ to 38.20. Statistically showing significance levels of DN3 are 95\% from M3 - M8 and DN2 group showing significant values of $\mathrm{p}<0.001$ when compared with Positive control. Among DN1 and DN2 and DN3 mutant peptides DN3 has showed maximum analgesic effect on mouse models but comparatively to $50-60 \%$ of standard Fentanyl compounds.

\section{CONCLUSIONS}

Analgesic peptides are promising candidates to replace chemical based opioid drug-based treatments in patients to get relief from pain during medical treatments. In the current study, synthetic mutated peptide Dynorphin is showing amicable results comparable to that of $50-60 \%$ of standard analgesics i.e. fentanyl compounds present in the market.

\section{ACKNOWLEDGEMENT}

The author is thankful for the financial support given under DBT-RGYI grant for carrying out these research studies.

\section{REFERENCES}

[1] Aldrich JV, McLaughlin JP. Opioid peptides: potential for drug development. Drug Discov Today Technol 2012;9(1):e23-e31.

[2] National Research Council (US) Committee on Recognition and Alleviation of Pain in Laboratory Animals. Recognition and alleviation of pain in laboratory animals. (Mechanisms of pain). Washington (DC): National Academies Press (US) 2009.

[3] Peckham AM, De La Cruz A, Dufresne RL. Kappa opioid receptor antagonism: are opioids the answer for treatment resistant depression? Ment Health Clin 2018;8(4):175-83.

[4] Sehgal N, Smith HS, Manchikanti L. Peripherally acting opioids and clinical implications for pain control. Pain Physician 2011;14(3):249-58.

[5] Fang WJ, Murray TF, Aldrich JV. Design, synthesis and opioid activity of arodyn analogs cyclized by ring-closing metathesis involving Tyr (allyl). Bioorg Med Chem 2018;26(6):1157-61.

[6] Machelska H, Celik MÖ. Advances in achieving opioid analgesia without side effects. Front Pharmacol 2018;9:1388.

[7] Kapitzke D, Vetter I, Cabot PJ. Endogenous opioid analgesia in peripheral tissues and the clinical implications for pain control. Ther Clin Risk Manag 2005;1(4):279-97.

[8] Jiang Y, Peng T, Gaur U, et al. Role of corticotropin releasing factor in the neuroimmune mechanisms of depression: examination of current pharmaceutical and herbal therapies. Frontiers in Cellular Neuroscience 2019;13:290.

[9] Shojaosadati SA, Kolaei SMV, Babaeipour V, et al. Recent advances in high cell density cultivation for production of recombinant protein. Iranian Journal of Biotechnology 2008;6(2):63-84.

[10] Yekkirala AS, Roberson DP, Bean BP, et al. Breaking barriers to novel analgesic drug development. Natl Rev Drug Discov 2017;16(8):545-64.

[11] Cabot PJ. Immune-derived opioids and peripheral antinociception. Clin Exp Pharmacol Physiol 2001;28(3):230-2.

[12] Lötsch J, Geisslinger G. Pharmacogenetics of new analgesics. $\mathrm{Br}$ J Pharmacol 2011;163(3):447-60. 